\title{
Assessment of Investment Attractiveness of Agroindustrial Complex in Republic of Bashkortostan
}

\author{
Krioni Olga \\ Department of Finance and Economic Analysis \\ Ufa State Aviation Technical University (USATU) \\ Ufa, Russia \\ okrioni@mail.ru \\ Efimenko Natalia \\ Department of Language Communication and \\ Psycholinguistics \\ Ufa State Aviation Technical University (USATU) \\ Ufa, Russia \\ efimenko@ufanet.ru
}

\author{
Pashchenko Svetlana \\ Department of Finance and Economic Analysis \\ Ufa State Aviation Technical University (USATU) \\ Ufa, Russia \\ svivnc@mail.ru \\ Boltyrov Vadim \\ Department of Finance and Economic Analysis \\ Ufa State Aviation Technical University (USATU) \\ Ufa, Russia
}

\begin{abstract}
Theoretical aspects of the agroindustrial complex, investment attractiveness of the sector and assessment techniques are considered based on the literature review in this article. In the analytical part of the work, state analysis of the agroindustrial complex of the Republic of Bashkortostan is made on the basis of statistical data; valid conclusions are drawn according to the analysis results. The result of the research in this article is to develop proposals for improving the investment attractiveness of the agroindustrial complex of the Republic of Bashkortostan.
\end{abstract}

Keywords - agroindustrial complex, investment attractiveness, rating, expert, efficiency matrix, risks, optimization.

Stable and effective development of Russian regions has to be provided with the outperforming growth rates of labor productivity and therefore sufficient volume of capital investments. In modern conditions, one of the most urgent problems is searching for new approaches and methods for increasing investment in the economy of regions, which ensure the economic development of the territories. [10]

At the same time, the economic condition of a significant number of regions is determined by agricultural industry and other branches of the agroindustrial complex. Therefore, stirring up the investment activity in this economic sector lays the foundation for a dynamic solution of the existing production and socio-economic problems of regions. It is the development of investment activities of the agroindustrial complex that stimulates actions to improve the general welfare and provision of the population.
At the present stage, it is possible to attract investments and accelerate their economic development through the formation of investment attractiveness and management of this process. [10]

In order to make decisions about investments in the agroindustrial complex of the Republic of Bashkortostan, it is necessary to estimate investment attractiveness of the region in general and the agroindustrial complex in particular.

For assessment and the comparative analysis of investment attractiveness of the Republic of Bashkortostan, the technique of news agency "UNIVERSE" is used. This technique has the advantage that covers a large number of factors and contains integrated indicators for all groups and for factors in general.

According to this technique, factors of investment attractiveness are grouped into 3 blocks: socio-political, domestic economic and external economic.

The technique is as follows: each risk group is described by a certain quantity of factors. Each factor reflects a specific aspect of development of the socio-political and economic situation; its current or forecasted state is characterized by a quantitative indicator. Scores are given taking into account these factors, which are estimated by 5 experts. The values of these indicators are estimated from 1 - the best - to 10 - the worst, and determined by the calculation or expert method in points. And each of the indicators in the assessment system has its weight corresponding to its significance. The sum of weights within each risk group is equal to 1 [1].

The quantitative score, assigned to the indicator (from 1 to 10 ), is multiplied by its weight (from 0 to 1 ), and the result is the contribution of each indicator to the considered risk group. 
The generalized assessment for all groups of risk (R) is written as follows:

$$
\mathrm{R}=\sum_{\mathrm{i}} \mathrm{A}_{\mathrm{i}} * \mathrm{~W}_{\mathrm{i}}
$$

where: $\mathrm{Ai}$ - average value of each indicator; indicator.

$$
\text { W - weighting coefficient of the corresponding }
$$

For the comparative assessment of investment attractiveness of the Republic of Bashkortostan, the regions were chosen according to the territorial neighborhood: the Republic of Tatarstan, the Chuvash Republic, Orenburg Region and Samara Region. These regions are a part of the Volga Federal District and Volga Economic Region. [4], [5], [6], [7]

The summary characteristic of average scores is presented in the form of a summary table. The region that gets in the aggregate the greater value of $\mathrm{R}$ is the most insecure economically and the least investment-attractive.

TABLE I. RISK ASSESSMENT OF REGION INVESTMENT ATTRACTIVENESS

\begin{tabular}{|l|c|c|c|c|c|}
\hline & $\begin{array}{c}\text { Republic of } \\
\text { Bashkortos } \\
\text { tan }\end{array}$ & $\begin{array}{c}\text { Republic } \\
\text { of } \\
\text { Tatarstan }\end{array}$ & $\begin{array}{c}\text { Orenburg } \\
\text { region }\end{array}$ & $\begin{array}{c}\text { Chuvash } \\
\text { Republic }\end{array}$ & $\begin{array}{c}\text { Samara } \\
\text { region }\end{array}$ \\
\hline $\begin{array}{l}\text { Socio- } \\
\text { political } \\
\text { factors }\end{array}$ & 3.36 & 2.62 & 3.92 & 4.34 & 3.86 \\
\hline $\begin{array}{l}\text { Domestic } \\
\text { economic } \\
\text { factors }\end{array}$ & 3.81 & 2.68 & 5.22 & 5.00 & 4.50 \\
\hline $\begin{array}{l}\text { Foreign } \\
\text { economic } \\
\text { factors }\end{array}$ & 3.24 & 2.32 & 4.71 & 4.97 & 4.89 \\
\hline R & 10.41 & 7.62 & 13.85 & 14.31 & 13.25 \\
\hline
\end{tabular}

The investment rating of the Republic of Bashkortostan is in the 2nd place. [3]

The Republic of Bashkortostan can be characterized as the region with a high level of investment activity. Also it should be noted that Bashkortostan takes the 2nd place among the regions with the minimum risks. As the table shows that the total weighted assessment of the Republic of Bashkortostan is equal to 10,41 .

The republic is inside the top ten subjects of the Russian Federation in terms of the key macroeconomic indicators, taking the 3rd place in the output of agricultural products, the 6th place - in the residential house commissioning, the 7 th place - in the volumes of paid services and works, rendered to the population performed by the type of economic activity "Construction", the 8th place - in the volume of investment into fixed capital. [3]
The Republic of Bashkortostan has a stable and controlled financial system based on the high level of tax collection, effective management of public finances.

The Republic of Bashkortostan is pursuing an active policy of establishing and developing economic, scientific, technical and cultural ties with the regions of the Russian Federation. Interregional cooperation is an important factor of economic development of the republic. Bashkortostan maintains trade and economic relations with 81 territorial subjects of the Russian Federation. [2]

Based on the analysis of available investment, the potential of the Republic of Bashkortostan is characterized as the region having the territory with a combination of good investment potential, a high level of investment security. In addition, it retains the reputation of a business partner and a good borrower.

In addition to the expert evaluation, it is necessary to assess the feasibility of investing in the agricultural complex.

The rationale of the optimal sectoral investment structure for the region from the viewpoint of investment attractiveness appears to be a complex and non-trivial task due to the simultaneous impact of multiple factors on investment processes. Therefore, first of all, there is a question about the set of factors, taken into account in modeling, as well as indicators of the optimality of the studied system state; and the indicator values will be considered in making decisions on the sectoral structure of investments.

In the proposed conceptual model, it is intended to use assessments of risk and investment efficiency for each branch as the criteria for making a decision. [8]

The investment efficiency is understood as the ratio of the increment in net profit to the volume of investment resources.

It is necessary to calculate the efficiency indicators for each branch, using the following formula:

$$
\mathrm{IEj}=\frac{(N P \mathrm{~N}+1-\mathrm{NPj})}{\mathrm{Ij}}=\frac{\Delta N P}{\mathrm{Ij}}(2)
$$

where: $\mathrm{IE}_{\mathrm{j}}$ - efficiency of investments carried out in the period of $\mathrm{j}$;

$\mathrm{NP}_{\mathrm{j}}$ and $\mathrm{NP} \mathrm{j}_{\mathrm{j}+1}-$ margins of net profit obtained in the period of investment and the next period, respectively; period of $\mathrm{j}$;

$I_{j}-$ the volume of investment, carried out in the

$\Delta \mathrm{NP}$ - increment in net profit.

Optimization experiments with this model allow us to identify the most investment-attractive sectors and justify the optimal structure of investments.

In order to formalize the model in the most convenient way for computer modeling, investment efficiency matrices were built. 
TABLE II. MATRIX OF INVESTMENT EFFICIENCY IMPLEMENTED IN THE REPUBLIC OF BASHKORTOSTAN IN THE SPHERES OF THE AGROINDUSTRIAL COMPLEX [3], [4]

\begin{tabular}{|c|c|c|c|c|c|c|c|}
\hline \multirow{2}{*}{ Industry } & \multicolumn{5}{|c|}{ Years } & \multirow{2}{*}{$\begin{array}{l}\text { mean } \\
\text { value }\end{array}$} & \multirow{2}{*}{ dispersion } \\
\hline & 2012 & 2013 & 2014 & 2015 & 2016 & & \\
\hline \multicolumn{8}{|c|}{ Livestock production. million rubles. } \\
\hline $\begin{array}{l}\text { Total. of } \\
\text { which: }\end{array}$ & 0.131 & -0.085 & 0.082 & 0.116 & 0.019 & 0.052 & 0.0062 \\
\hline $\begin{array}{c}\text { Livestock } \\
\text { number }\end{array}$ & 0.145 & -0.088 & 0.082 & 0.113 & 0.048 & 0.060 & 0.0065 \\
\hline Cattle & 0.133 & -0.087 & 0.082 & 0.112 & 0.021 & 0.052 & 0.0063 \\
\hline Pigs & 0.101 & -0.092 & 0.078 & 0.100 & 0.211 & 0.080 & 0.0095 \\
\hline $\begin{array}{c}\begin{array}{c}\text { Sheep and } \\
\text { goats }\end{array} \\
\end{array}$ & 0.142 & -0.086 & 0.087 & 0.120 & 0.043 & 0.061 & 0.0065 \\
\hline Horses & 0.132 & -0.086 & 0.084 & 0.116 & 0.038 & 0.057 & 0.0061 \\
\hline Fur farming & 0.447 & -0.089 & 0.069 & 0.105 & 0.074 & 0.121 & 0.0310 \\
\hline $\begin{array}{l}\text { Poultry } \\
\text { stock }\end{array}$ & 0.125 & -0.087 & 0.084 & 0.118 & 0.010 & 0.050 & 0.0063 \\
\hline $\begin{array}{l}\text { Hens and } \\
\text { roosters }\end{array}$ & 0.118 & -0.090 & 0.089 & 0.120 & -0.005 & 0.046 & 0.0067 \\
\hline Geese & 0.124 & -0.077 & 0.103 & 0.089 & 0.020 & 0.052 & 0.0053 \\
\hline Turkeys & 0.141 & -0.086 & 0.066 & 0.133 & 0.033 & 0.057 & 0.0068 \\
\hline $\begin{array}{l}\text { Honey-bee } \\
\text { family. } \\
\text { one } \\
\text { thousand } \\
\text { families }\end{array}$ & 0.233 & 0.052 & 0.053 & 0.082 & 0.011 & 0.086 & 0.0059 \\
\hline \multicolumn{8}{|c|}{ Crop production. million rubles. } \\
\hline $\begin{array}{l}\text { Total. of } \\
\text { which: }\end{array}$ & -0.092 & 0.035 & -0.105 & 0.089 & 0.001 & -0.014 & 0.0055 \\
\hline $\begin{array}{c}\text { Grain } \\
\text { (in weight } \\
\text { after } \\
\text { completion) }\end{array}$ & -0.123 & 0.067 & -0.105 & 0.108 & 0.000 & -0.011 & 0.0083 \\
\hline $\begin{array}{c}\text { Sugar } \\
\text { beet }\end{array}$ & -0.116 & 0.156 & -0.098 & 0.093 & -0.003 & 0.006 & 0.0112 \\
\hline \begin{tabular}{|c|}
$\begin{array}{c}\text { Sunflower } \\
\text { seeds }\end{array}$ \\
\end{tabular} & -0.127 & 0.161 & -0.099 & 0.110 & -0.014 & 0.006 & 0.0128 \\
\hline $\begin{array}{c}\text { Corn. } \\
\text { green forage }\end{array}$ & 0.160 & -0.037 & -0.116 & 0.063 & 0.009 & 0.016 & 0.0087 \\
\hline $\begin{array}{c}\text { Fodder root } \\
\text { crops }\end{array}$ & 0.103 & -0.038 & -0.109 & 0.066 & 0.008 & 0.006 & 0.0056 \\
\hline \multicolumn{8}{|c|}{ Food production. million rubles. } \\
\hline $\begin{array}{l}\text { Total. of } \\
\text { which: }\end{array}$ & 0.048 & -0.003 & 0.047 & 0.031 & 0.035 & 0.032 & 0.000424 \\
\hline $\begin{array}{c}\text { Meat and } \\
\text { meat } \\
\text { products }\end{array}$ & -0.002 & 0.007 & 0.035 & 0.046 & 0.037 & 0.024 & 0.000430 \\
\hline $\begin{array}{l}\text { Fish and } \\
\text { processed } \\
\text { and } \\
\text { preserved } \\
\text { food }\end{array}$ & 0.025 & 0.012 & 0.031 & 0.032 & 0.041 & 0.028 & 0.000109 \\
\hline $\begin{array}{l}\text { Milk and } \\
\text { dairy } \\
\text { products }\end{array}$ & 0.024 & 0.012 & 0.035 & 0.032 & 0.030 & 0.027 & 0.000080 \\
\hline
\end{tabular}

\begin{tabular}{|c|c|c|c|c|c|c|c|}
$\begin{array}{c}\text { Eggs and } \\
\text { egg } \\
\text { products. } \\
\text { millions of } \\
\text { pieces }\end{array}$ & 0.021 & 0.006 & 0.024 & 0.016 & 0.018 & 0.017 & 0.000043 \\
\hline $\begin{array}{c}\text { Bread and } \\
\text { bakery } \\
\text { products }\end{array}$ & 0.030 & 0.016 & 0.033 & -0.018 & 0.122 & 0.037 & 0.002659 \\
\hline Potatoes & 0.301 & -0.053 & 0.137 & 0.042 & 0.027 & 0.091 & 0.018408 \\
\hline Vegetable & 0.071 & -0.013 & 0.073 & 0.024 & 0.050 & 0.041 & 0.001321 \\
\hline Fruit & 0.093 & -0.033 & 0.117 & 0.022 & 0.053 & 0.050 & 0.003506 \\
\hline Berries & 0.067 & -0.252 & 0.041 & 0.061 & 0.056 & -0.006 & 0.019006 \\
\hline
\end{tabular}

The data, used to implement the model, characterize the dynamics and efficiency of investments in the Republic of Bashkortostan in 2011-2016. [3] Matrices are presented in Table II. The elements of matrices are the indicators of the efficiency of livestock production, crop production and food production in the $\mathrm{i}$-year for the $\mathrm{j}$-branch of the agroindustrial complex of the Republic of Bashkortostan as well as the average values of indicators.

The risk level for branches of the agroindustrial complex is heterogeneous. If one proceeds from the dispersion values given in Table II, investment in fur farming should be recognized the most risky in the structure of livestock in terms of investment efficiency, and investment in poultry production and beekeeping is the least risky.

Due to the fact that the level of investment efficiency and the degree of risk are different for different branches, it is necessary to study the optimal structure of investments in the agroindustrial complex of the Republic of Bashkortostan based on the criterion of investment attractiveness. Whereas investment attractiveness is based on the criteria of investment efficiency and risk criteria.

It is proposed to use a nonlinear optimization economicmathematical model, based on the Markowitz-Tobin and Sharpe models, in order to solve the optimization problem.

The adaptation of these models is based on the premise that systemic risks are inherent in the branches due to the impact of the same factors combination. The existence of these risks objectively causes interannual fluctuations in the investment effectiveness for both individual sectors and the entire economic system of the region as a whole.

At the same time, the risk can be divided into two types: the one that is caused by fluctuations in the efficiency for each of the branches and that caused by the risk, consisting in possible simultaneous orientation of fluctuations of several branches at the same time.

The mathematics model is as follows. The independent variables of the model are $\mu \mathrm{i}$. It is a share of investment in the i-branch from the total annual aggregate of investment into the economy of the region.

1. The average expected efficiency of investments in the i-industry (xi) is calculated as the arithmetic mean of the efficiency indicators over the past years: 


$$
\overline{\mathrm{x}_{\mathrm{i}}}=\frac{1}{\mathrm{n}} \sum_{\mathrm{j}=1}^{\mathrm{n}} \mathrm{x}_{\mathrm{ij}}
$$

2. The expected efficiency of investments by sector (Xp) is the sum of products of average expected efficiency indicators by shares in the total volume of investments in the relevant branches:

$$
X_{p}=\sum_{i=1}^{m} \mu_{i} \bar{x}_{i}
$$

3. The amount of investment shares should be equal to 1 (the condition of full use of the whole set of investments).

4. In order to preserve the sectoral structure of investment, it is desirable that the shares of investment by the decision do not exceed the minimum and the maximum of those observed during the time horizon of the study:

$$
\min \left\{\lambda_{i j}\right\} \leq \mu_{i} \leq \max \left\{\lambda_{i j}\right\}_{(5)}
$$

where $\{\chi i j\}$ - a set of values for shares of the i-branch in the structure of investments into j-year.

The upper and lower bounds of shares can be also defined.

$$
\text { 5. Restrictions on the efficiency of }
$$
investments.

The Markowitz-Tobin models use restrictions according to which the optimal investment structure must have an efficiency of at least a certain level.

This model uses restrictions according to which the optimal investment structure should have efficiency which is not lower than the average value for the past years.

Since such restrictions do not always allow modeling the least risky investment options, optimization was performed in the study, taking into account this restriction and without it.

The priority in modeling the region investment attractiveness is the use of an indicator that reflects the degree of stability of the investment efficiency indicator for branches and territorial entities.

6. The risk, characterized by fluctuations of investment efficiency indicators for each of branches (R1), is:

$$
R_{1}=\sum_{i=1}^{m} \mu_{i}^{2} \sigma_{i}^{2}
$$

where: $\sigma_{t}{ }^{2}-$ dispersion of investment efficiency in the ibranch for the considered period.

7. The risk, characterized by the possible unidirectional fluctuations of the branch investment efficiency indicators (R2), is:

$$
R_{2}=\left|\sum_{i=1}^{m} \sum_{k} 2 \cdot \mu_{i} \cdot \mu_{k} \cdot \operatorname{cov}\left(x_{i}, x_{k}\right)\right|
$$

8. The overall risk of investment efficiency $(R c)$ is:

$$
R_{c}=\sqrt{R_{1}+R_{2}}
$$

9. Also the Sharpe (S) criterion, representing the ratio of the expected investment efficiency to the total risk, can be used to determine the optimal investment structure:

$$
S=\frac{\bar{X}_{p}}{R_{c}}
$$

Therefore, the optimization problem is to justify the optimal investment structure, taking into account the assessment of the risk level and investment attractiveness of individual industries.

As a criterion of optimality, one can choose:

1. Maximizing the investment effectiveness at the most acceptable level of risk (c):

$$
\overline{\mathrm{X}_{\mathrm{p}}} \rightarrow \max , \quad \mathrm{R}_{\mathrm{c}} \leq \mathrm{c} . \mathrm{R}_{\mathrm{c}} \leq \mathrm{c}
$$

2. Minimizing the overall risk (with possible indication in the block of restrictions of the minimum acceptable level of investment efficiency $(d)$ ):

$$
\mathrm{R}_{\mathrm{c}} \rightarrow \min , \quad \overline{\mathrm{X}_{\mathrm{p}}} \leq \mathrm{d} .(11)
$$

3. Maximizing the ratio of investment efficiency to the overall risk (with possible indication in the block of restrictions of the minimum acceptable level of investment efficiency $(d)$ ):

$$
\mathrm{S} \rightarrow \max , \quad \overline{\mathrm{X}_{\mathrm{p}}} \leq \mathrm{d} .
$$

Optimization models were implemented in MS Excel 2013 using the built-in module "Solver" ("Solution search").

For each of the variants, there were performed five optimization experiments differing in the choice of the optimality criterion and the minimum acceptable level of investment efficiency.

In three optimization options, the minimum possible level of efficiency was not limited, but in others, it was adopted at the level of average values of the period under consideration.

Similarly, the authors determine the overall risk of investment efficiency both without restrictions and with the possible indication of the minimum acceptable level of investment efficiency. 
The results of optimization experiments, taking into account the existing investment structure in the region, the sectoral risk criteria and the investment attractiveness of livestock production, crop production and food production are presented in Tables III-V.

TABLE III. OPTIMIZATION RESULTS OF LIVESTOCK BRANCH STRUCTURE

\begin{tabular}{|c|l|l|l|l|l|}
\hline \multirow{2}{*}{ Industry } & \multicolumn{4}{|c|}{$\begin{array}{l}\text { Without restrictions on the } \\
\text { lower bound of efficiency }\end{array}$} & \multicolumn{3}{|c|}{$\begin{array}{l}\text { With restrictions on } \\
\text { the lower } \\
\text { efficiency }\end{array}$} \\
\cline { 2 - 6 } & max Xp & min Rc & max S & min Rc & max S \\
\hline Cattle & 0.0524 & 0.0394 & 1.3299 & 0.0395 & 1.3266 \\
\hline Pigs & 0.0795 & 0.0235 & 3.3830 & 0.0237 & 3.3544 \\
\hline $\begin{array}{c}\text { Sheep and } \\
\text { goats }\end{array}$ & 0.0612 & 0.0321 & 1.9065 & 0.0323 & 1.8947 \\
\hline Horses & 0.0587 & 0.0423 & 1.3877 & 0.0425 & 1.3812 \\
\hline $\begin{array}{c}\text { Fur farming } \\
\text { Hens and } \\
\text { roosters }\end{array}$ & 0.0675 & 0.0387 & 1.7442 & 0.0389 & 1.7352 \\
\hline Geese & 0.0654 & 0.0345 & 1.8957 & 0.0346 & 1.8902 \\
\hline Turkeys & 0.0589 & 0.0426 & 1.3826 & 0.0428 & 1.3762 \\
\hline $\begin{array}{c}\text { Honey-bee } \\
\text { families }\end{array}$ & 0.0863 & 0.0112 & 7.7054 & 0.0113 & 7.6372 \\
\hline
\end{tabular}

Currently the natural and resource potential contributes to the development of beekeeping. The products of beekeeping are widely used not only as the main product - honey, but also as the products of its processing in medicine, cosmetology. In terms of volumes and quality of produced honey, the Republic of Bashkortostan is a leader in the Russian Federation, being its main exporter of these products. Poultry industries are currently profitable and highly efficient industries as the demand for products is consistently high. However, the poultry market in the Republic of Bashkortostan is not saturated; a large amount is imported from neighboring regions.

TABLE IV. OPTIMIZATION RESULTS OF CROP BRANCH STRUCTURE

\begin{tabular}{|c|c|c|c|c|c|}
\hline \multirow{2}{*}{ Industry } & \multicolumn{3}{|c|}{$\begin{array}{l}\text { Without restrictions on the } \\
\text { lower bound of efficiency }\end{array}$} & \multicolumn{2}{|c|}{$\begin{array}{c}\text { With restrictions } \\
\text { on the lower } \\
\text { bound of } \\
\text { efficiency }\end{array}$} \\
\cline { 2 - 6 } & $\max \mathrm{Xp}$ & $\min \mathrm{Rc}$ & & $\max \mathrm{Xp}$ & $\min \mathrm{Rc}$ \\
\hline $\begin{array}{c}\text { Grain } \\
\text { (in weight after } \\
\text { completion) }\end{array}$ & 0.0035 & 0.4621 & 0.0076 & 0.4623 & 0.0076 \\
\hline Sugar beet & 0.0025 & 0.5305 & 0.0047 & 0.5307 & 0.0047 \\
\hline $\begin{array}{c}\text { Sunflower seeds } \\
\text { Corn, green } \\
\text { forage }\end{array}$ & 0.0021 & 0.5022 & 0.0042 & 0.5024 & 0.0042 \\
\hline \begin{tabular}{c} 
Fodder root crops \\
\hline
\end{tabular} & 0.0184 & 0.2345 & 0.0785 & 0.2346 & 0.0784 \\
\hline
\end{tabular}

To solve the problem, it is necessary to implement an investment program for the re-profiling of existing facilities, as well as the construction of new production facilities, including feed milling production and deep processing [9].

TABLE V. OPTIMIZATION RESULTS OF FOOD BRANCH STRUCTURE

\begin{tabular}{|c|c|c|c|c|c|}
\hline \multirow[t]{2}{*}{ Industry } & \multicolumn{3}{|c|}{$\begin{array}{l}\text { Without restrictions on the } \\
\text { lower bound of efficiency }\end{array}$} & \multicolumn{2}{|c|}{$\begin{array}{c}\text { With restrictions on } \\
\text { the lower bound of } \\
\text { efficiency }\end{array}$} \\
\hline & $\begin{array}{c}\max \\
\mathrm{Xp}\end{array}$ & $\min R c$ & & $\max X p$ & $\min \mathrm{Rc}$ \\
\hline $\begin{array}{l}\text { Meat and meat } \\
\text { products }\end{array}$ & 0.0586 & 0.0424 & 1.3821 & 0.0426 & 1.3756 \\
\hline $\begin{array}{c}\text { Fish and the } \\
\text { processed and } \\
\text { preserved foods }\end{array}$ & 0.0613 & 0.0302 & 2.0298 & 0.0303 & 2.0231 \\
\hline $\begin{array}{l}\text { Milk and dairy } \\
\text { products }\end{array}$ & 0.0507 & 0.0457 & 1.1094 & 0.0460 & 1.1022 \\
\hline $\begin{array}{l}\text { Eggs and egg } \\
\text { products, } \\
\text { millions of } \\
\text { pieces }\end{array}$ & 0.0446 & 0.0616 & 0.7240 & 0.0619 & 0.7205 \\
\hline $\begin{array}{c}\text { Bread and } \\
\text { bakery products }\end{array}$ & 0.0987 & 0.0102 & 9.6765 & 0.0103 & 9.5825 \\
\hline Potatoes & 0.0486 & 0.0624 & 0.7788 & 0.0627 & 0.7751 \\
\hline Vegetable & 0.0786 & 0.0221 & 3.5566 & 0.0223 & 3.5247 \\
\hline Fruit & 0.0786 & 0.0204 & 3.8529 & 0.0206 & 3.8155 \\
\hline Berries & 0.0786 & 0.0213 & 3.6901 & 0.0215 & 3.6558 \\
\hline
\end{tabular}

Potato production is the least attractive in the sectoral structure of food production. At present, the production of potatoes in the Republic of Bashkortostan is concentrated in the individual and small-scale sectors $(95-97 \%$ of the total planting area), i.e. potato has become almost exclusively an allotment crop.

Also the production of eggs is less attractive and the most risky for food production. The reason for the decline in the production of eggs is the reduction in the production capacity of the poultry farms of the Ural-Volga agroindustrial group (Poultry Farms "Bashkirskaya", "Tuimazinskaya" and "Yubileynaya"). In addition, there are problems in providing the population with poultry meat. At an annual rate of $30 \mathrm{~kg}$ of poultry per capita, republican enterprises produce only $18 \mathrm{~kg}$. There is a need to increase production due to the low supply of breeding eggs in the Republic of Bashkortostan.

The optimization results can be used to select the most appropriate sectoral investment structure according to the interests of any of the participants in the economic relations, depending on the orientation to maximum efficiency, minimum risk or the best ratio. The most attractive ones from the standpoint of the integrated effect are variants that provide the minimum risk and the maximum ratio of investment and risk efficiency taking into account the restriction of the minimum efficiency for economic entities at the average statistical level of the past years (Table VI). 
TABLE VI. OPTIMIZATION RESULTS OF INVESTMENT BRANCH STRUCTURE FROM THE POSITIONS OF INTEGRATED EFFECT

\begin{tabular}{|c|c|c|c|c|c|}
\hline \multirow[t]{2}{*}{ Industry } & \multicolumn{3}{|c|}{$\begin{array}{l}\text { Without restrictions on the } \\
\text { lower bound of efficiency }\end{array}$} & \multicolumn{2}{|c|}{$\begin{array}{lr}\text { With restrictions } \\
\text { on the lower } \\
\text { bound } \\
\text { efficiency }\end{array}$} \\
\hline & $\begin{array}{l}\max \\
\mathrm{Xp}\end{array}$ & $\min \mathrm{Rc}$ & & $\begin{array}{l}\max \\
\mathrm{Xp}\end{array}$ & $\min \mathrm{Rc}$ \\
\hline \multicolumn{6}{|c|}{ Efficiency for the spheres of the agroindustrial complex } \\
\hline $\begin{array}{l}\text { Livestock } \\
\text { production }\end{array}$ & 0.4022 & 0.3906 & 1.0296 & 0.3910 & 1.0286 \\
\hline Crop production & 0.2446 & 0.6789 & 0.3602 & 0.6791 & 0.3601 \\
\hline Food Production & 0.7598 & 0.1784 & 4.2589 & 0.1787 & 4.2518 \\
\hline
\end{tabular}

Based on the above stated information, it can be concluded that currently in the Republic of Bashkortostan, food production remains the most attractive and the least risky as shown in Table VI.

The developed technique gives the opportunity to explore the investment attractiveness of individual industries and their various complexes with given restrictions.

\section{References}

[1] Boltyrov V. A., Krioni O.V., Pashchenko S.N. Approaches to assessment of the enterprise investment attractiveness. Kazan science. Vol. 9, pp. 22-26, September 2015

[2] The resolution of the government of the Republic of Bashkortostan of April 18, 2016 Vol. 188 "About the adoption of Investment Development Strategy in the Republic of Bashkortostan till 2020 "http://bashstat.gks.ru/wps/wcm/connect/rosstat_ts/bashstat/ru/statistics/f inance/.

[3] https://economy.bashkortostan.ru/dejatelnost/strategicheskoeplanirovanie/strategiya-razvitiya-respubliki-bashkortostan/.

[4] http://tatstat.gks.ru/wps/wcm/connect/rosstat_ts/tatstat/ru/reporting/.

[5] http://orenstat.gks.ru/wps/wcm/connect/rosstat_ts/orenstat/ru/statistics/fi nance/.

[6] http://www.chuvash.gks.ru/wps/wcm/connect/rosstat_ts/chuvash/ru/stati stics/finance/.

[7] http://samarastat.gks.ru/wps/wcm/connect/rosstat_ts/samarastat/ru/statist ics/finance/.

[8] Akhmadeev, M.G., Gerasimova, O.E., Bagautdinova, N.G., Arzhantseva, N.V. «Current risk factors and some aspects of prospective development of agro-industrial complex potential in tatarstan: Financial, investment, innovative». Asian Social Science. Vol. 11(11), pp. 206-213, November 2015.

[9] Hajiyev, P., Mingaleva, Z. Main ways of attracting investments into agriculture and agro-industrial complex of Russia. Life Science Journal. Vol. 10(4), pp. 824-829, April 2013.

[10] Varlamova, M. Investment and innovation attractiveness of agroindustrial processing industr. Economic Annals-XXI. Vol. 9-10(2), pp. 10-13, February 2013 